\title{
PT3 Stage Finding
}

National Cancer Institute

\section{Source}

National Cancer Institute. pT3 Stage Finding. NCI Thesaurus. Code C48768.

A pathologic primary tumor TNM stage finding. The definition of PT 3 stage finding depends on the particular type of cancer that it refers to; for example, for breast cancer, PT 3 stage finding is defined as follows: cancer with tumor size more than $5.0 \mathrm{~cm}$ in greatest dimension; for kidney cancer, pT3 stage finding is defined as follows: cancer with tumor extending into major veins or perinephric tissues but not into the ipsilateral adrenal gland and not beyond Gerota's fascia. (from AJCC 7th Ed.) 